\title{
Challenges in United Nations Peacekeeping Operations
}

\author{
N. N. H. Nordin \\ Centre of Graduate Studies, National Defence University of Malaysia \\ Sungai Besi Camp, Kuala Lumpur, Malaysia \\ E-mail: nani_nhn93@yahoo.com
}

Wan Norhasniah Wan Husin (Corresponding author)

Faculty of Defence Studies \& Management, National Defence University of Malaysia

Sungai Besi Camp, Kuala Lumpur, Malaysia

E-mail: hasniah@upnm.edu.my

\begin{abstract}
M. Z. Salleh
Faculty of Defence Studies \& Management, National Defence University of Malaysia

Sungai Besi Camp, Kuala Lumpur, Malaysia

E-mail: zainisalleh@upnm.edu.my
\end{abstract}

Received: Nov. 3, 2021 Accepted: Dec. 20, 2021 Published: Jan. 9, 2022

doi:10.5296/ijssr.v10i1.19141ＵRL: https://doi.org/10.5296/ijssr.v10i1.19141

\begin{abstract}
Given the variety of actions concentrating on peacekeeping with significant successful operations, the United Nations (UN) continues to encounter concerns and challenges that have hampered its peacekeeping operations' efficiency, effectiveness, and performance. This article aimed to investigate the primary challenges that adversely influence peacekeeping operations and challenge them based on the security theory proposed by Barry Buzan. According to the study's findings, UN peacekeeping missions have been successful in addressing conflict situations and promoting peace in many regions of the world. Nevertheless, faults and challenges, notably in terms of the operations' political, economic, and societal factors, have restricted the peacekeeping operations' ability to achieve their objectives successfully. Therefore, a better policy that includes all involved actors, especially local government and the population, should be established in order to rebuild a conflict-torn
\end{abstract}


country.

Keywords: challenges, peacekeeping operations, politics, economy, social 


\section{Introduction}

The primary purpose of the UN establishment was to ensure international peace and security, which has been accomplished through the implementation of peacekeeping operations. It's also an excellent method for preventing and removing threats to today's global stability and peace concerns, and it's one of the most effective tools for dealing with them and establishing long-term peace in war-torn countries (Fortna, 2010). Peacekeeping operations have been effective in assisting countries such as Côte d'Ivoire in re-establishing security and stability. It is fundamentally a collaborative effort that can only succeed if all participants, including the Security Council, military and police contributions, regional organizations, and host nations, stand up and do their role. The character of UN peacekeeping operations varies. Some of the main activities connected with UN peacekeeping include aiding and assisting cease-fire treaties, facilitating crises to seek alternatives, supervising ordinance, and non-military elements such as providing emergency aid and political restoration such as helping the restoration of representative government, protecting and promoting human rights and the rule of law.

Despite remarkable victories, it is also observed that throughout history, particularly in multi-dimensional settings, UN peacekeepers have faced significant challenges due to a variety of concerns relevant to various sectors of peacekeeping operations. In the 21 st century, UN peacekeeping forces face more challenging obstacles, such as assaults on peacekeepers, complicated mandates, and inconsistent political provisions, which the troops must handle to perform effectively (Sarjoon \& Yusoff, 2019). Thus, the proper running of UN peacekeeping operations is challenged by a variety of difficulties. For the context of this research, we believe that challenges in the political, economic, and societal areas are more relevant and pose a more significant threat to peacekeeping operations based on the Security Theory by Barry Buzan, which will be explained later in the next section.

Peacekeeping political actions are connected with reinstating democratization, the rule of law, and good governance, such as assisting in conducting the electoral process, comprising observation, judiciary reformation, and empowering civil society. The Declaration of Common Positions on UN Peacekeeping Operations (2018) highlights the importance of politics in resolving disputes. Two levels of political debate are addressed in the Declaration. Most of the piece, which claims to be about "political solutions to violence," is basically about easing diplomatic exchanges between "peacekeeping actors" in New York. It emphasizes; (i) Security Council judgement, (ii) the connections between mandates and resource discussions within General Assembly, and (iii) engagements with Troop and Police Contributing Countries (TCCs and PCCs). The Declaration's brief section on the "influence of peacekeeping on maintaining international peace and security" fixates focus on how UN peacekeepers interact with politics on the field. This underlines the need for; (i) missions to collaborate better with local authorities, (ii) missions to interact with the local population, and (iii) missions to assure that the multitude of UN entities in theatre integrates their efforts more efficiently (Gowan, 2019). This section emphasizes the importance of the UN to work more closely and effectively with national governments and non-state entities and resolve societal issues. 
The funding of UN peacekeeping operations has been difficult for the secretary-general from its beginning, with times of quiet followed by moments of crisis. Withheld and late payments from the UN's most prominent financial donors have posed a significant threat. Since 2016, the US has begun to delay a part of its payment and accumulate debts, putting pressure on UN peacekeeping operations (Wasim, 2019). Suspending payments influences the efficiency of operations and the deployment capacity of troop-contributing countries. Overcoming the capital difficulties that peacekeeping faces will take the UN membership's joint effort and inventiveness. Economic factors related to the existence of a peacekeeping operation in a specific location involve; (i) services catering to foreign troops, such as those provided by hotels, eateries, cafeterias, and in the manufacturing and transportation industries; (ii) high-and low-skilled positions open to mission personnel; and (iii) all downstream economic effects of these actions on other industries (Jennings \& Bos, 2015).

UN peacekeeping operations in the 21 st century are no longer limited to observing and monitoring ceasefire lines. There are no defined boundaries or battlefields in most war zones, and dangers and obstacles to peace are not centered on any specified geographical place. Instead, the issues are societal. Peacekeepers are expected to assist states in enhancing their ability to provide security and maintain social order, to boost the rule of law and cultivate universal human rights, to motivate political engagement, to endorse the formation of legitimate political institutions, to increase financial recovery and development, and to repopulate or return refugees and internally displaced persons (IDPs) (Borisov, 2017). Since criminals utilize, places devastated by war, the battle against narcotics and organized crime is also crucial to the effectiveness of peacekeeping operations (Caparini, 2019). Natural resources are typically a vital part of conflict management, livelihoods, and confidence-building at the community scale, and peacekeeping operations have considerable natural resource consequences as well as substantial environmental effects. In circumstances where natural resources such as diamonds, gold, oil, and lumber have ignited or supported hostilities or have been militarized, UN peacekeeping forces must be granted a more comprehensive mandate to assist national authorities in reconstructing natural resource governance. Other than that, with more natural resource clauses in peace treaties nowadays, it is evident that the world community, specifically peacekeeping operations, must develop new capabilities and alliances to assist in executing these measures (United Nations Environment Programme, 2012). It is crystal clear that peacekeeping operations encounter a lot of dynamic challenges throughout the deployment. Therefore, this paper is intended to discuss the challenges based on the security factors proposed by Barry Buzan's security theory.

\section{Security Theory}

In his work "People, States, and Fear," Barry Buzan (1991) highlights five security sectors connected to threats: military, political, economic, societal, and environmental. For Barry Buzan, the military threat is the most prominent challenge for a nation. All sectors of the country are vulnerable to military threats. It has the potential to seriously undermine a state's fundamental responsibility to safeguard its people, as well as to harm layers of individual and social purpose. However, the relevance of the degree and intentions of military threats can vary, and the notion that they include the use of force places them in a unique class when it 
comes to security. Political challenges, according to Buzan, are also a constant source of worry for a nation, yet they are more complex and harder to identify than military aggression. Since the state is a political institution in and of itself, it can take the shape of ideological conflict or assault the country as a whole.

As said by Buzan, "the typical state of participants in a market economy is one of risk, fierce competition, and unpredictability," and this insecurity makes economic security challenging to separate. He addresses the critical link between economic and military security. Due to budget constraints and limitations, it is clear to understand how military security is dependent on financial security. Identity and the balance which can be established inside any given state are fundamental to societal concerns. Weak states are frequently ill-equipped to deal with cultural and identity issues. Using Afghanistan as an illustration, it is clear that the variations in culture, ideology, and ethnicity that compose tribal divisions inside the country are difficult to come to terms with the country itself. The majority of current conflicts have a societal factor to them. It is also crucial to note that the concept of "societal security" is hard to implement because it deals with cultures and identities, which are fundamentally subjective and circumstantial ideas that can offend some people and discriminatory politics.

The environmental sector is likewise complex to describe and is the most debatable among the five sectors. When considering potential ecological hazards, they frequently emphasize the "human conflict with nature," such as floods and earthquakes. These events are uncontrollable on their own. The more recent challenges of human impact on the globe, resulting in occurrences such as climate change, pollution, and ozone depletion, to mention a few, that's where we could see more obviously a controllable factor in terms of the environment. Buzan said that all these factors are essential, and while military factors are the most focused on, other factors such as economic and societal ones should be given attention as well. As mentioned above, for this paper, we focused on political issues, economic constraints, and societal factors.

\section{UN Peacekeeping Operations Background}

The UN defined peacekeeping as an operation involving army troops without enforcement powers created by the United Nations to help preserve peace and stability in war-torn countries (United Nations, 1996). It is a method for maintaining international peace and security whenever violence has ceased and assists in implementing peace accords by peacekeepers (Castellan, 2010). The first UN peacekeeping operations were launched in 1948 and 1949, consecutively, in response to conflicts in the Middle East and along the India-Pakistan frontier (Thakur \& Schnabel, 2001; Osmanczyk, 2003). Since their inception, peacekeeping missions have gone through three stages of evolution. The first phase involves traditional peacekeeping operations, the second phase involves multi-dimensional peacekeeping operations, and the third phase is more geared towards governance missions.

Peacekeepers are deployed in the first phase, the classic peacekeeping operation phase, in reaction to conflicts between two or more factions, usually involving two or more countries (Standardized Generic Training Module, 2009). This operation aims to create a favourable climate to find a peaceful resolution to the problem for both parties concerned. In order to 
avoid misconceptions during the peacekeeping operation, the peacekeeping force must understand the culture of the local people in the countries in conflict. Traditional peacekeeping operations also attempt to oversee national borders, monitor secured areas, prevent minor crises from growing and provide military advice so that political discussions for a settlement can occur more fully (Bellamy \& Griffin, 2010). In this scenario, peacekeepers are permitted to use force in self-defense. Traditional peacekeepers are typically drawn from small and neutral countries such as Australia and New Zealand in that particular conflict (Baumgärtner, 2014). Examples of traditional peacekeeping operations are the United Nations Truce Supervision Organization (UNTSO) in the Middle East and the United Nations Military Observer Group in India and Pakistan (UNMOGIP).

The second phase, multidimensional peacekeeping operations, comes after the Cold War when war or conflict no longer involves two different countries but rather an internal crisis within a country that leads to war (Standardized Generic Training Module, 2009). However, from an objective standpoint, the operation retains the objectives of traditional peacekeeping operations, with the difference being several things, such as assisting local authorities in enforcing the law, helping the country's judiciary, monitoring human rights, controlling and regulating the electoral process, monitoring the ceasefire process, and, last but not least, assisting local governments in rebuilding the country. The United Nations Operation in Liberia (UNMIL) and the United Nations Operation in Bosnia and Herzegovina (UNMIBH) are two examples of multidimensional peacekeeping operations (Mandoyi et al., 2013).

On the other hand, the third phase is more focused on the mission of governance in the country, also known as transitional power in the country. Under this category, peacekeeping operations have been permitted to operate as the interim administrator or management for the country or region until the situation gradually stabilizes and local enforcement is ready to take over (Standardized Generic Training Module, 2009). To achieve these objectives, the warring parties must maintain a high level of openness, cooperation, and tolerance to solve the dispute. For example, peacekeeping operations under the governance phase include the United Nations Transitional Authority in Cambodia (UNTAC).

\section{Methodology}

This research is a descriptive and interpretive qualitative research project. Only secondary sources, such as scholarly articles, books, and UN peacekeeping operation department documents, were used in the research. These resources have documented the primary activities of peacekeeping operations, their successes, and the challenges due to them. This research focused on the UNPKO's challenges in political issues, economic constraints, and societal factors. In this study, quotations, summaries, and the researchers' interpretation explanations are used to convey the main research findings.

\section{Discussion}

Despite the productive and successful stories of UN peacekeeping, peacekeeping operations have gotten more complicated due to the complexity of inter-state and intra-state disputes and problems linked to the numerous dimensions of UN peacekeeping. Because of obstacles 
related to components of peacekeeping, the operations' achievements have always been doubted and condemned. The section that follows discusses the primary challenges, particularly in terms of political issues, economic constraints, and societal factors that impede the effectiveness of UN peacekeeping operations.

\subsection{Political Issues}

According to Buzan's security theory, political security is about authority relationships, governing position and recognition. Some people may seek to distinguish between legal and political sectors. When discussing the national security issue, he mentioned that the state is made up of individuals tied together in a collective political unit, representing political theory ethical view (Buzan \& Albert, 2011). Therefore, the political security in a nation should be given attention, especially in war-torn countries. Political issues have a role in making UN peacekeeping operations problematic. The host country's consent, the political situation of the post-conflict environment, the operation's mandate, and sufficient equipment and training from the UN headquarters are among the prominent and vital aspects that impede the efficient process of peacekeeping.

\subsubsection{Host Country's Consent}

The United Nations has embraced the core principle that operations should only be deployed with the approval of the host-state government and the other sides to a dispute. The host-state government hindering peacekeepers' activities and procedures in various methods can prohibit peacekeepers from carrying out their duty and pose significant dangers to the peacekeepers' protection and wellbeing. Because host nation approval is a core premise of UN peacekeeping, the host country has the right to veto a UN peacekeeping operation (Sebastián \& Gorur, 2018). As per Buzan (1991), political threats might come from the government within the state itself. The United Nations Mission in Sudan (UNMIS) has been directly confronted with this difficulty due to the Sudanese government's refusal to comply with the UN peacekeeping mission. UNMIS was designed to aid in the enforcement of the Comprehensive Peace Agreement (CPA), which ended years of conflict between North and South Sudan. Sudan's authority has consistently refused to engage with UN peacekeepers as well as other humanitarian groups, refusing them the liberty of movement and accessibility, declining visas for essential people, and, on several occasions, delaying the supply of logistical support for the accomplishment of the UN mission (Akpan \& Olisah, 2019).

\subsubsection{Political Stability of the Post-Conflict Situation}

Political instability in a nation might impose challenges for national security. The weak and fragile state might return to the brink of war if the unstable political situation (Buzan \& Little, 2000). Another critical concern threatening the UN peacekeeping mandate is a lack of political confidence and a fundamental readiness to demobilize. Furthermore, one of the most challenging issues in UN peacekeeping is maintaining stability without establishing ground peace (Osmanczyk, 2003). Another military challenge in peacekeeping is the UN's structural inadequacy. The UN's lack of adequate planning strategies, misguided procurement processes, a semi-permanent financing recession and a lack of personnel, special forces units, and 
technological advances, as well as logistical and transportation insufficiencies, have all contributed to crucial circumstances in UN peacekeeping, particularly in demilitarization and demobilization operational processes.

\subsubsection{Operation's Mandate}

Another issue with UN peacekeeping is that the mandates establish ties with the nation's authority without incorporating them in the development and discussion of the mandates. State sovereignty and governance are also important factors. The relationship between all security actors in a state, such as politicians, police forces, intelligent services, etc., plays an essential role in maintaining a nation's security and peace (Buzan \& Hansen, 2009). Consequently, regional organizations, host governments, and affected populations should be appropriately incorporated into the drafting of UN mandates, and exit and sustainability strategies in ways apart from peacekeeping must be developed (Stockholm Forum, 2019). For example, the United Nations Organization Stabilization Mission in the Democratic Republic of the Congo (MONUSCO), which has been stationed in the nation since 1999, can barely safeguard its inhabitants from the numerous hazards that threaten their lives. In South Sudan, peacekeepers suffer the same problems. They are charged with violating the concept of impartiality, which is a primary value of peacekeeping alongside the permission of the parties and the non-use of force except in self-defense. The lack of clarity concerning the vital components of UN peacekeeping operations, particularly regarding the concept of impartiality, is a significant cause of the blue helmet's loss of credibility in Africa (Salaun, 2019).

\subsubsection{Sufficient Logistic Support and Training}

Buzan acknowledges that the war on terror has taken its toll on specific countries. Therefore, he stressed that states should safeguard their security against penetration by terrorists and the vulnerability of infrastructure, which is vital for a government and state to function (Buzan, 2006). Infrastructure and logistics should adhere to each operational situation's dynamic environment and political difficulty described for peacekeeping operations. The logistical assistance for every operation is determined by the origin and accountability of the aid to the force deployed, which immediately influences the operational activities required (Cid \& Goldoni, 2016). The first phase of a peacekeeping mission is crucial for establishing logistics. Many people and equipment need to be brought to the host country, where their entry and transit to the operational area should be facilitated. In rural parts, establishing a fundamental logistical network of support through the lease of buildings, infrastructures for shelters, highways, airbases, and warehouses becomes very tough (Coleman, 2014).

The UN operations encounter significant logistical challenges, including delays caused by limited UN equipment resources, limited purchasing accessibility, extended shipping times, and the complexities required in obtaining liquid funds for purchasing. There are long delays between the Security Council's authorization of a new assignment and the Secretariat's corresponding effects to prepare and deploy peacekeeping troops, police forces, observers, equipment, and supplies (Nagar, 2018). These gaps have significant effects, since they often reduce an operation's political movement and operational efficiencies, leading to a dead-end 
in national peace guarantee.

One of the obstacles of UN peacekeeping in Africa is training, ideology, and the difficulty of command structure. The UN peacekeeping missions are led by a multinational force consisting of troops and personnel from several nations with varying military training and ideology. These disparities show up in the field and harm the operation's command structure. When some contingents refused to cooperate with or collaborate with others, command and control has been a severe difficulty for the UN (Alli, 2012; Akpan \& Olisah, 2019).

\subsection{Economic Constraint}

According to Buzan (1991), economic security can be used as a crucial indicator of a country's overall security. When comparing developed and developing countries, it is evident that economic security makes other degrees of security simpler to construct. The overall number of UN peacekeeping forces on the ground has nearly tenfold increase over the last decade, resulting in an overburdened system. The expenditure for peacekeeping operations was increased fivefold, reaching a new high of US \$7.06 billion in 2014-2015 (UN News Center, 2017). Another critical issue that makes peacekeeping operations particularly challenging is a lack of international financial assistance for peacekeeping and little or no support from all UN member countries. No country has ever paid the agreed-upon fee for UN peacekeeping operations as scheduled. Due to delayed payments and suspension of assessed contributions, UN peacekeeping missions are experiencing cash flow shortages and financial strains (International Peace Institute, 2019). As a result, there was a lot of disagreement among participating nations about how to fund peacekeeping operations.

Prior to the outbreak of the pandemic, funding constraints in UN peacekeeping missions had already created tensions. Military, police, and civilian UN troops have expressed dissatisfaction with their lack of resources to complete required tasks, a problem that has been voiced regularly at UN Headquarters. As a result, layoffs have become a familiar and utterly depressing scenario for civilian peacekeeping personnel, which are UN personnel, unlike their military colleagues. Between 2010 and 2018, the number of civilian peacekeeper roles fell by $37 \%$, from 22,437 to 14,162 , and hundreds of more posts were terminated in 2019 (Coleman, 2020, 2021).

According to Buzan et al. (1998), security is the maneuver that pushes politics further than the accepted norms of the game. It presents the problem as an actual threat, necessitating emergency procedures and justifying measures beyond the standard political practice. Securitization's fundamental ingredients are present in the international response to COVID-19: referent object(s), risk, audiences, securitizing actions and agents, and emergency measures. The politics of securitization, on the other hand, is neither straightforward nor unproblematic. COVID19 has occurred during a period of retrenchment and financial constraint for UN peacekeeping. Between 2015 and 2019, total approved UN peacekeeping spending fell by more than $21 \%$, from $\$ 8.47$ billion in $2014 / 2015$ to $\$ 6.65$ billion in 2019/2020 (United Nations, 2021). This decrease highlighted the termination of operations in Côte d'Ivoire, Liberia, and Haiti, as well as ongoing pressure from significant financial donors to cut expenditures in current operations, especially those suffering severe 
political and security issues. The United States, which currently pays roughly $28 \%$ of UN peacekeeping expenditures, has frequently led these requests (United Nations, 2018; Donais \& Tanguay, 2020).

The direct budgetary consequence of COVID-19 on UN peacekeeping missions is unclear. Missions have encountered unanticipated costs for COVID-19 preventative measures, but some of these can be covered by current funds. MONUSCO, for example, used Quick Impact Project funds to provide COVID-19-fighting equipment and supplies to the provincial government of South Kivu in the Democratic Republic of Congo (United Nations Peacekeeping, 2020). Short-term savings can also be achieved by halting activities and delaying troop rotations. Future outlook, unfortunately, considerable peacekeeping funding cuts are inevitable as the pandemic's financial implications fuel new demands for cost savings (Coning, 2020). As a result, economic burdens will be experienced at UN Headquarters in New York and UN peacekeeping operations.

\subsection{Societal Factor}

According to Buzan et al. (1998), threats range from stifling societal expression to interfering with its ability to thrive and include things like massacring residents, prohibiting the use of language, and so on. Repressive measures against the manifestation of identity would also pose a threat to society's reproduction. Identity cannot be modified if the institutions for replicating language and culture are not allowed to function. Law enforcement agencies and other agencies' efforts to re-establish the rule of law are hampered by a lack of cultural awareness of local circumstances and an inadequate objective. Low enforcement practices among multinational troops could have a disastrous impact on peacekeeping operations. According to Hansen, the most severe effect is a loss of trust, respect, and credibility among local law enforcement officers and the general public (Hansen, 2002). Cultural and linguistic variations represent a severe obstacle to UN peacekeeping operations in Africa and other countries. As personnel of the force failed to grasp the common cultural identity in Sudan, the problem of cultural and language gaps created an impediment to the peacekeeping mission, resulting in operational disruptions and other obstructions. Some contingents came to Somalia without knowing anything about the country, its history, culture, or current affairs. As a result, for peacekeeping to be broadly accepted by the people it was designed to serve, it must be culturally aware (Duffey, 2000).

One of the factors that make UN peacekeeping missions challenging is a lack of collaboration within the deployment. The ability of military peacekeeping personnel, non-governmental organizations (NGOs), and other civilian personnel to carry out the duties of peacekeeping operations is substantially strengthened. Simultaneously, civilian police must meet all of its operation partners (Sarjoon \& Yusoff, 2019). For example, the UN Refugee Agency in Kosovo, the United Nations High Commissioner for Refugees (UNHCR), was upset by the UN Mission in Kosovo (UNMIK) police's incompetence to ensure protection for returning refugees (Hansen, 2002). The case of the European Union also highlights how politicians respond to societal vulnerabilities induced by shifting patterns of international migration and heightened attention in and sensitivity to refugee security issues (Buzan, 1993). Migration 
became a significant worry in the 1990s, not only in North America but in practically every country on the planet.

Misbehavior, violations of human rights, and abuse of armed troops are all issues that threaten UN peacekeeping missions. There have been incidents of international peacekeeping soldiers misbehaving in almost every task, with Cambodia being a prime example. Some contingents engaged in heinous acts such as exploiting the local populace, black-marketing and operating a prostitution ring (Hatto, 2013; Hansen, 2002). Peacekeeping operations in Iraq and Afghanistan have also seen several violations and abuses. In the vast majority of cases, UN employees have been immune from local jurisdiction and are only bound by the laws of their home country. Every country has its own set of rules. As a result, some behaviors may be perfectly lawful in one nation but not in the other. Several troop-contributing countries were cautious about taking the necessary preventive (training deployed troops to cope with war zones) and corrective (punishing personnel for excessive misbehavior) procedures (UN News Center, 2014).

The societal security challenge may intensify to the point where resources are depleted, or one party is eliminated through abhorrent expressions such as ethnic cleansing or genocide or by weakening the opponent, causing tremendous and especially permanent damage to the players. Such manifestations aim to wipe out the other's social existence, which is why civilians, women, children, and youth are the favored targets since they are the seeds of society's continuity and generation (Buzan, 1991). Another critical difficulty regarding UN peacekeeping is the abduction of humanitarian relief. It is incredibly challenging for peacekeepers to carry out humanitarian missions amid a long-running armed civil war. The significant challenges that peacekeeping personnel encounter are kidnapping, hostage-taking, and the murder of humanitarian workers by insurgent or unknown armed organizations (Insecurity Insight, 2020; United Nations, 2014; Feingold, 2018). In several circumstances, this was visible amid peacekeeping operations. As a result, peacekeepers encounter difficulties in dispersing humanitarian aid as scheduled.

Pandemic Covid-19 adds to the operational obstacles encountered by peacekeepers attempting to stop the conflict that contributes to the growth of weaponry, wildlife smuggling, more remarkable refugee migration, ethnic-based aggression, and violence targeting non-combatants. The decrement of peacekeeping forces during the crisis' restrictive measures (containment, working from home, border controls, personnel relocation, etc.) creates a gap for guerrilla leaders. They could use this timeframe to re-establish their legislation by channeling global attention and focus on reinstating peace and stability. On the other hand, the COVID-19 situation, with its forced incarceration and diminished patrolling on the ground, could lead to new militias and armed organizations, further fragmenting the already fragmented territory affected by the war (Tchinda, 2020).

\section{Conclusion}

UN peacekeeping operations continued as one of the most successful instruments to preserve international security and stability. It maintained a complex and challenging mission, reacting to ongoing instability in inter-state interaction and armed conflict within territorial limits. 


\section{Macrothink Institute ${ }^{\mathrm{TM}}$}

However, for peacekeeping to remain an instrument for sustaining world peace, Member States must guarantee that deployments are given specific mandates and the requisite personnel and funds to carry them out. Mandates should be constructed after a thorough discussion that includes local authorities. As stated previously, UN peacekeeping has become highly challenging due to several political issues, economic constraints and societal factors, as highlighted by Buzan. It is worth mentioning that the capability and desire to restructure and improve peacekeeping and rethink its position in conflict transformation will determine its survival as a middle ground alternative between disengagement and implementation. To better cope with the remaining forces of military conflicts, the United Nations, Member States, and other vital stakeholders must collaborate closely to create the proper means to make peacekeeping succeed by considering political issues, economic constraints, and societal factors, as stated by Buzan. In the future, this strategy will improve synergy between the three elements and growth-related actions of UN peacekeeping operations.

\section{References}

Akan, N. E., \& Olisah, C. I. (2019). The Challenges and Prospects of United Nations Peacekeeping Mission in Africa. International Multi-Disciplinary Journal, 13(3), 80-91. https://doi.org/10.4314/afrrev.v13i3.7

Alli, W. O. (2012). The Role of Nigeria in Regional Security Policy. Abuja: Friedrich Ebert Stiftung.

Baumgärtner, U. (2014). Gender and Peacekeeping: A Process of Norm Adaptation in the United Nations Bureaucracy. Unpublished master thesis. University of St. Gallen, Gender and Peacekeeping School of Management, Economics, Law, Social Sciences and International Affairs.

Bellamy, A., \& Griffin, S. (2010). Understanding Peacekeeping (2nd ed.). Malden, MA: Polity Press.

Borisov, D. (2017). A Difficult Peace: The UN and the Challenges of Modern Peacekeeping. Russian Council. Retrieved from https://russiancouncil.ru/en/analytics-and-comments/analytics/a-difficult-peace-the-un-and-th e-challenges-of-modern-peacek/

Buzan, B. (1991). People, States and Fear: An Agenda for International Security Studies in the Post-Cold War Era. Essex: Longman.

Buzan, B. (1993). Introduction: The Changing Security Agenda in Europe. In O. Waever, B. Buzan, M. Kelstrup \& P. Lemaitre (Eds.), Identity, Migration, and the New Security Agenda in Europe. London: Pinter.

Buzan, B. (2006). Will the 'global war on terrorism' be the new Cold War? International Affairs, 82(6), 1101-1118. https://doi.org/10.1111/j.1468-2346.2006.00590.x

Buzan, B., \& Albert, M. (2011). Securitization, Sectors and Functional Differentiation. Security Dialogue, 42(4-5), 413-425. https://doi.org/10.1177/0967010611418710 
Buzan, B., \& Little, R. (2000). International Systems in World History. Oxford: Oxford University Press.

Buzan, B., Waever, O., \& Wilde, J. D. (1998). Security: A New Framework for Analysis. Boulder: Lynne Rienner.

Caparini, M. (2019). UN Police and the Challenges of Organized Crime. SIPRI Discussion Paper. Retrieved from https://www.sipri.org/publications/2019/other-publications/un-police-and-challenges-organize d-crime

Castellan, P. M. (2010). Human Rights and Peacekeeping. Suite: Peace Operation Training Institute.

Cid, M. C. B., \& Goldoni, L. R. (2016). Logistic Complexity in Peacekeeping Operations: A Challenge. Austral: Brazilian Journal of Strategy \& International Relations, 6(11), 116-131. https://doi.org/10.22456/2238-6912.72185

Coleman, K. P. (2014). Political Economy of UN Peacekeeping. New York: International Peace Institute.

Coleman, K. P. (2020). Downsizing in UN Peacekeeping: The Impact on Civilian Peacekeepers and the Missions Employing Them. International Peacekeeping, 1-29. https://doi.org/10.1080/13533312.2020.1793328

Coleman, K. P. (2021). "Downsizing Survivor Syndrome” in UN Peace Operations. IPI Global Observatory. Retrieved from https://theglobalobservatory.org/2021/01/downsizing-survivor-syndrome-in-un-peace-operati ons/

Coning, C. (2020). COVID-19 will change the way the UN conducts peacekeeping operations in the future. Effective Peace Ops. Retrieved from https://effectivepeaceops.net/blog/covid-19-will-change-the-way-the-un-conducts-peacekeepi ng-operations-in-the-future/

Donais, T., \& Tanguay, E. (2020). Doing Less with Less? Peacekeeping Retrenchment and The UN's Protection of Civilians Agenda. International Journal: Canada's Journal of Global Policy Analysis, 75(1), 65-82. https://doi.org/10.1177/0020702020915209

Duffey, T. (2000). Cultural Issues in Contemporary Peacekeeping. In T. Woodhouse \& O. Ramotham (Eds.), Peacekeeping and Conflict Resolution. Oxon: Frank Cass Publishers. https://doi.org/10.1080/13533310008413823

Feingold, S. (2018). Two Aid Workers Killed. One Kidnapped, In Congo. CNN. Retrieved from https://edition.cnn.com/2018/02/19/africa/congo-aid-workers-killed/index.html

Fortna, V. P. (2010). Does Peacekeeping Work? Shaping Belligerents: Choices after Civil War. Princeton, Oxford: Princeton University Press.

Gowan, R. (2019). The Politics of Action for Peacekeeping. United Nations University. 
Retrieved from

https://cpr.unu.edu/publications/articles/the-politics-of-action-for-peacekeeping.html

Hansen, A. S. (2002). From Congo to Kosovo: Civilian Police in Peace Operations. New York: Oxford University Press.

Hatto, R. (2013). From Peacekeeping to Peacebuilding: The Evolution of the Role of the United Nations in Peace Operations. International Review of the Red Cross, 95(891/892), 495-515. https://doi.org/10.1017/S1816383114000277

Insecurity Insight. (2020). Aid Workers Kidnapped 2020. Retrieved from https://reliefweb.int/sites/reliefweb.int/files/resources/2020-Aid-Workers-Kidnapped.pdf

International Peace Institute. (2019). Financing UN Peacekeeping: Avoiding another Crisis. Retrieved from https://www.ipinst.org/wp-content/uploads/2019/04/1904_Financing-UN-Peacekeeping.pdf

Mandoyi, N., Choane, M., \& Twala, C. (2013). The Role of the International Multidimensional Peacekeeping Missions in Africa: A Case of Darfur (Sudan). Journal of Social Science, 36(1), 1-9. https://doi.org/10.1080/09718923.2013.11893167

Nagar, S. (2018). UN Peacekeeping Challenges, Solutions and South Asia's Stance. South Asian Survey, 23(1), 54-68. https://doi.org/10.1177/0971523118756399

Osmanczyk, E. J. (2003). Encyclopaedia of The United Nations and International Agreements. London: Routledge Publications.

Salaün, N. (2019). The Challenges Faced by U.N. Peacekeeping Missions in Africa. The Strategy Bridge. Retrieved from https://thestrategybridge.org/the-bridge/2019/10/14/the-challenges-faced-by-un-peacekeeping -missions-in-africa

Sarjoon, A., \& Yusoff, M. A. (2019). The United Nations Peacekeeping Operations and Challenges. Academic Journal of Interdisciplinary Studies, 8(3), 202-211. https://doi.org/10.36941/ajis-2019-0018

Sebastián, S., \& Gorur, A. (2018). UN Peacekeeping and Host-State Consent: How Missions Navigate Relationship with Governments. Washington D.C: Stimson Center.

Standardized Generic Training Modules for United Nations Peacekeeping. (2009).

Stockholm Forum on Peace and Development. (2019). Does Peacekeeping Work? Key Findings from Recent Research in The Democratic Republic of the Congo and Mali.

Tchinda, S. P. (2020). COVID-19: Challenge of Peacekeeping in Conflict-Affected Environments. Global Campaign for Peace Education. Retrieved from https://www.peace-ed-campaign.org/covid19-peacekeeping/

Thakur, R., \& Schnabel, A. (2001). United Nations Peacekeeping Operations: Ad hoc Missions, Permanent Engagements. Tokyo: United Nations University Press. 


\section{Macrothink}

International Journal of Social Science Research

ISSN 2327-5510 2022, Vol. 10, No. 1

UN News Center. (2014). Feature: UN's First Female Force Commander Talks Peacekeeping and Why She's Not Taking Her Harley to Cyprus. Retrieved from http://www.un.org/apps/news/story.asp?NewsID=47793

UN News Center. (2017). Peacekeeping Fact Sheet. United Nations Peacekeeping. Retrieved from http://www.un.org/en/peacekeeping/resources/statistics/factsheet.shtml

United Nations. (1996). The Blue Helmets: A Review of United Nations Peacekeeping (3rd ed.). New York: United Nations.

United Nations. (2014). Increased Attacks on Aid Workers Due to Lack of Respect for International Humanitarian Law, Deputy Secretary-General Tells Security Council. Retrieved from https://www.un.org/press/en/2014/sc11524.doc.htm

United Nations. (2018). Delegates Highlight Peacekeeping Budget Cuts amid Increasingly Complex Challenges, as Fourth Committee Continues Comprehensive Review. Retrieved from https://www.un.org/press/en/2018/gaspd678.doc.htm

United Nations. (2021). Fifth Committee Approves \$6.37 Billion Budget for 12 Peacekeeping Missions from July 2021 to June 2022, Concluding Resumed Session. Retrieved from https://www.un.org/press/en/2021/gaab4368.doc.htm

United Nations Environment Programme. (2012). Greening the Blue Helmets Environment, Natural Resources and UN Peacekeeping Operations. Retrieved from https://wedocs.unep.org/bitstream/handle/20.500.11822/8840/UNEP_greening_blue_helmets. pdf? sequence $=3 \& a m p \% 3$ BisAllowed $=$

Wasim, M. (2019). Financing UN Peacekeeping: Avoiding another Crisis. Retrieved from https://www.ipinst.org/wp-content/uploads/2019/04/1904_Financing-UN-Peacekeeping.pdf

\section{Copyrights}

Copyright for this article is retained by the author(s), with first publication rights granted to the journal.

This is an open-access article distributed under the terms and conditions of the Creative Commons Attribution license (http://creativecommons.org/licenses/by/4.0/). 